Hubert Wojciechowski

Politechnika Poznańska

E-mail: hubert.wojciechowski@put.poznan.pl

Łukasz Hadaś

Politechnika Poznańska

E-mail: lukasz.hadas@ @ut.poznan.pl

Filip Karaśkiewicz

Politechnika Poznańska

E-mail: filip.karaskiewicz@ put.poznan.pl

\title{
IDENTIFICATION AND CHARACTERISTIC OF NECESSARY TASKS IN IMPLEMENTING ENGINEERING CHANGES IN AUTOMOTIVE INDUSTRY
}

\begin{abstract}
Background: This chapter is devoted to the identification and characteristic of necessary tasks of implementing engineering changes in automotive industry. Each engineering change commissioned by a customer need a specific set of tasks to be implemented successfully in a company. Engineering changes affect especially these departments in companies: engineering, production, quality, logistics, warehouse and maintenance. Each task has its own rank and material scope. Identification and characteristic of necessary tasks of implementing engineering changes have to include customer specific requirements, industry, engineering and automotive industry standards. Complete list of tasks is required during planning, organizing and controlling the process of implementing engineering changes.
\end{abstract}

Methods: Based on the in-depth interview with experts from different automotive companies and results from survey let a list of necessary tasks of implementing engineering changes in automotive companies be created.

Results: The list of necessary tasks of implementing engineering changes in automotive companies include identification and characteristic of each task. Each task has been allocated to departments, whose involvement is required for successful implementation of engineering changes.

Conclusions: Project managers can use the list of necessary tasks of implementing engineering changes in automotive companies as a type of a check-list. This will provide project managers with wider view and fuller information during the processes of change 
management. Using this list can also be beneficent as a tool to prioritize tasks, because critical path of necessary tasks of implementing engineering changes in automotive companies, in most cases does not need all the task to be done before implementation. Some tasks can be done in less occupied times.

Keywords: engineering changes, change management process, automotive industry.

\section{INTRODUCTION TO IMPLEMENTING THE ENGINEERING CHANGES IN AUTOMOTIVE INDUSTRY}

The engineering changes is described in literature as "all kinds of activities aimed at the process of using the company's available resources to obtain the proposed future state in the course of negotiations with the client regarding the finished product" [Mikołajczyk 2003]. The engineering change in the product contains many components and does not only affect management, but also organization, economics, technology, and even psychology and sociology [Bartnicki 1998]. Change management is a separate, specialized management method [Clarke 1997].

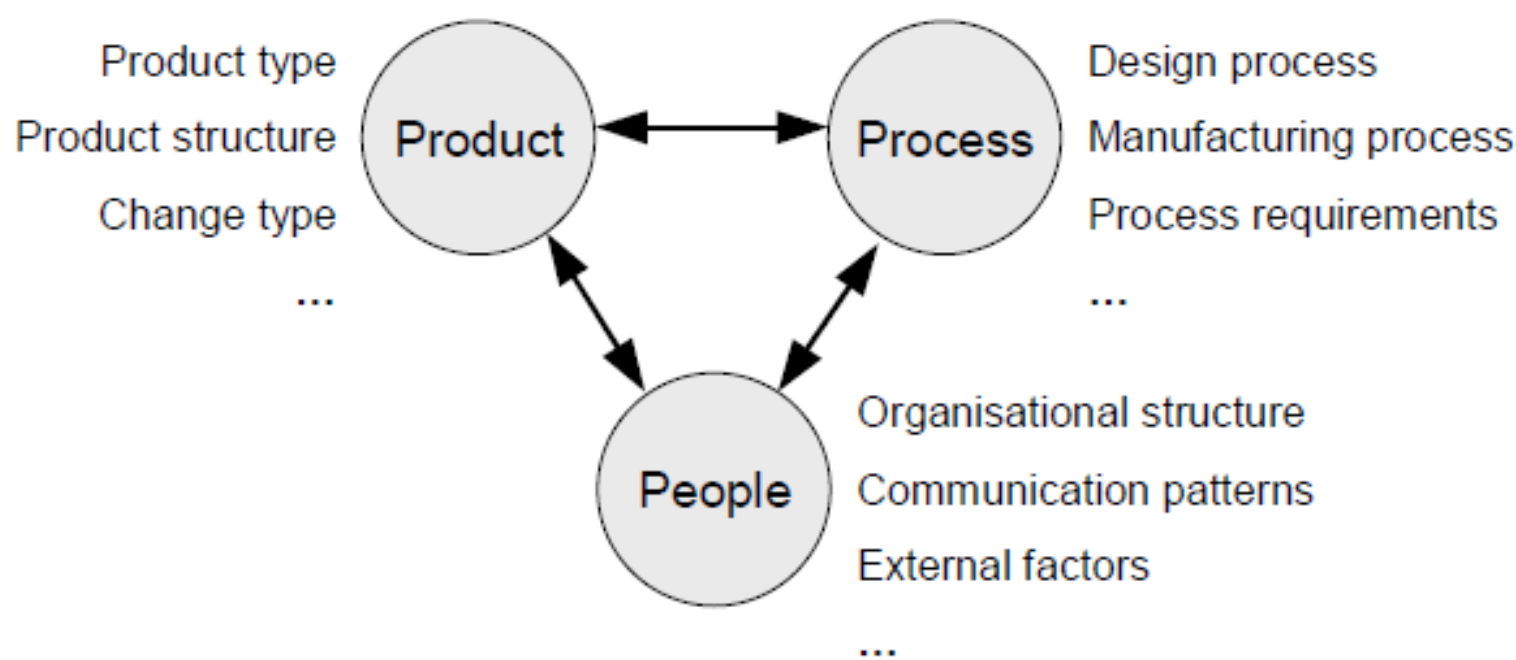

Figure 1. Interactions the product development process and the change process. Source: [Eger, Eckert, Clarkson, 2007]

The scope of engineering changes relates to human resources management, processes with product and the product itself (fig.1). In automotive company those changes can affect:

Operations (e.g. logistics, production, after-sales)

Product lifecycle management (configuration management, collaboration \& disciplines integration, system engineering, modules \& re-use, monitoring):

- Local processes \& tools (e.g. electrical, software, mechanical, processes, purchasing) 
- External (e.g. suppliers, partners, subcontractors) [Urban-Galindo and Ripailles 2019.]

Based on literature analysis authors decided that engineering changes term in this chapter will be understood as activities using company's resources to fulfil customer needs by changing and managing whole organization (product, process and people).

The authors, while conducting research using the method of in-depth structured interviews, noticed that engineering changes require many different activities that are not always product-related, but may relate to economic aspects in terms of the cost-effectiveness of introducing a given engineering change. The sociological and psychological knowledge of managers is also often used during employee training in order to quickly understand the reasons for introducing a given engineering change by production employees. The scope of strategic management is not taken directly into account when introducing engineering changes in products in the automotive industry. However, it is included in negotiations regarding the scope of implementation of a given change with the client.

Most often, an engineering change in a product is caused by external factors [Wirkus, Roszkowski, Dostatni and Gierulski 2014]. Mainly in the automotive industry they are customers who order such a change. Much less often there is a need to implement an engineering change caused by internal factors, and even then, due to the specificity of the automotive industry, such a change must be forwarded to the customer whose product the change concerns. In the process of implementing engineering changes there are three main stages: design, ordering \& configuration and production planning \& realization [Buergin et al. 2018]. Each company in automotive industry needs to be able to implement changes in products. "It is crucial for companies to continuously introduce innovative products and make variations to existing products to remain competitive in the market" [Rossini 2016]. This ability is called changeability [ElMaraghy 2009]. There is also flexibility which relates to implementing changes during assembly processes [Koren 2010]. The rate of product change requests, based on Volkswagen AG data from 2010 - 2013 years, grow up by 300\% [Sivri, Krallmann 2015].

In the general design, there is no specific and formalized template for change request document, and in another template such document is set by the project team. Any change that the customer would like to apply should be included in such an application [Wysocki 2005]. The change request itself initiates only the procedure of implementation engineer changes. All steps of the change management implementation should be controlled. Controlling change management steps in the project may be as follows:

- $\quad$ Integrated change control (communication with project participants), 
- Formalized application registration procedure (some independent decision of the project manager is allowed),

- Classification of the application into one of the established categories (external, internal, other),

- Giving opinions on the application (project manager, change control committee, experts),

- Assessment of potential effects of changes (risk, costs, schedule, other consequences),

- Assessment of possible solutions (causes, effects and conditions of modification),

- Analysis of the impact of changes on the project (timeliness, costs, scope, quality),

- Redefining project parameters (based on the analysis of budget deviations, schedule and scope of work),

- Presentation of the results of the analysis of the Change Control Committee or Steering Committee (approval or rejection of the application),

- Implementation and documentation of results (acceptance of modifications for implementation or registration of rejection).” [Bukłaha 2012].

In the automotive industry, an engineering change is realised in accordance with the customer requirements. A key document containing a number of information necessary for making changes in automotive industry is Customer Specific Requirements (CSR). The CSR document covers only the borders, in which supplier can move to fulfil OEM's requirements. CSR documentation does not determine the processes. [CSR: Daimler AG 2017, BMW Group 2017, Ford Motor 2017, General Motors 2019, PSA 2017, Volkswagen 2018, IATF 16949: 2016]. The formalized application registration procedure is recorded in CSR documents. The material scope of changes in implementation the engineering change in the automotive industry also consists in determining what elements of the process a given engineering change will affect. To determine what will be affected in a company usually department managers, product managers and client delegation need to create all of necessary tasks for implementation the engineering change. Next step is to ask, for an opinion, all required departments. This opinion is the basis for making a decision on the acceptance of the request for engineering change. For changes proposed by the customer that cause increased costs, the rates for a given finished product may be renegotiated. Solutions most often involve a change or modification of the machine park, a change in the model design, or a decision on what to do with the products before the change. After obtaining information on solutions, company's management can develop elements based on the potential effects of changes that 
will be affected by the change in the product. The results of the analysis can be used to negotiate with the client to introduce additional entries in the request for engineering change. Acceptance of the change for implementation causes distribution of tasks to be performed by all required departments.

The specificity of the automotive industry in the field of implementing engineering changes is particularly noticeable in terms of the deadlines set for introducing changes and the speed of achieving satisfactory final results obtained after introducing the change in the scope of the finished product delivered to the customer.

\section{RESEARCH METHODOLOGY}

The main goal of the research is to identify and characterize the necessary tasks related to engineering changes in the automotive industry. To achieve this goal, the following research methodology was subordinated. The methodology includes the following steps:

- In-depth interview with experts with experience in implementing technical changes in the automotive industry;

- Preparation of the list of tasks, as well as the initial allocation to departments;

- Preparation of a survey questionnaire, CAWI research;

- Analysis of results of CAWI research,

- Preparation of the final list with a brief description.

The first stage of the research was based on in-depth interview with experts with experience in implementing technical changes in the automotive industry. As a result of the work, a list of tasks was created, with an initial assignment of tasks to departments and a specification of the material scope of each task. In the next step, a questionnaire has been prepared to verify the list of tasks. The research was carried out using the CAWI method. The list of tasks was verified by managers and senior specialists from the automotive industry (from tier 1 suppliers, which work directly with OEM companies). Managers and specialists verified the list of required tasks based on several years of experience in their own departments involved in the process of implementing engineering changes. Finally, based on analysis of results of CAWI research, final list has been prepared.

\section{LIST AND CHARACTERISTICS OF EACH NECESSARY TASKS IN IMPLEMENTING ENGINEERING CHANGES IN AUTOMOTIVE INDUSTRY}


In the following part of this chapter, there are 65 different necessary tasks in implementing engineering changes in automotive companies identified and characterized. Each task is also assigned to one of four main departments in automotive industry. Main departments are: engineering, production, quality and logistics with purchasing. Each of these tasks were consulted with corresponding chair of department.

Each task must have at least one main department and may need support from auxiliary departments. Main department is defined as a leader for a task. Auxiliary department can be asked to conduct certain operations for a selected task, but their role is not significant. Departments in columns "main departments" and "auxiliary departments" are sorted in descending order in terms of their degree of involvement in realised tasks.

Material scope of changes can be: product, direct process, indirect process, organizational change, change of documentation. Material scope of the change during the implementation of the activity can concern:

- product (change of dimensions, functionality, product structure, material),

- direct process (technological process of product processing, eg: plastic and thermal processing, operations and assembly techniques),

- indirect process (auxiliary process: transport, quality control, warehouse operations, product and / or process identification),

- organizational change (training, change in the structure of resources, change of responsibility, work schedule),

- change of documentation (development of new documentation, updating the database).

Engineering department is responsible for these tasks (table 1.).

Table 1. List of tasks from engineering department

\begin{tabular}{|c|c|c|c|c|c|}
\hline $\begin{array}{c}\text { Task } \\
\text { number }\end{array}$ & Name of task & Description & $\begin{array}{c}\text { Main } \\
\text { departments } \\
\text { or customer }\end{array}$ & $\begin{array}{l}\text { Auxiliary } \\
\text { departments or } \\
\text { customer }\end{array}$ & $\begin{array}{c}\text { Material scope of } \\
\text { changes }\end{array}$ \\
\hline 1 & $\begin{array}{l}\text { Engineering Change } \\
\text { Notice (ECN) } \\
\text { Procedure Launch }\end{array}$ & $\begin{array}{l}\text { Launching the procedure for implementing } \\
\text { the engineering change. Asking for an } \\
\text { opinion (assessment) members of the team } \\
\text { responsible for the product and process } \\
\text { affected. ECN is the initiation point for the } \\
\text { company after business agreement with } \\
\text { customer. ECN Procedure Launch is } \\
\text { assigned mainly to Engineering department. }\end{array}$ & $\begin{array}{c}\text { Engineering } \\
\text { Quality }\end{array}$ & $\begin{array}{l}\text { Customer } \\
\text { The head of } \\
\text { production } \\
\text { unit } \\
\text { Production } \\
\text { department }\end{array}$ & Product \\
\hline 2 & Capacity check & $\begin{array}{l}\text { Checking whether the introduced } \\
\text { engineering change will affect machine park } \\
\text { capacity. If yes it should be calculated in } \\
\text { business agreement. }\end{array}$ & Engineering & Not required & Direct process \\
\hline 3 & $\begin{array}{c}\text { Preparing 3D model } \\
\text { design }\end{array}$ & $\begin{array}{l}\text { Preparing 3D model with change. } \\
\text { Additionally, check assembly environment if } \\
\text { there is no negative influence of parts } \\
\text { crashes, possible temperature, fluid, } \\
\text { electricity influence on environment. }\end{array}$ & Engineering & Not required & Product \\
\hline 4 & Material change & Changing the material from which the & Engineering & Production & Product \\
\hline
\end{tabular}

Brzeziński Ł. et al. (Eds.), Modern solutions in production and warehousing, Spatium, Radom 2019. 
MODERN SOLUTIONS IN PRODUCTION AND WAREHOUSING

\begin{tabular}{|c|c|c|c|c|c|}
\hline $\begin{array}{c}\text { Task } \\
\text { number }\end{array}$ & Name of task & Description & $\begin{array}{l}\text { Main } \\
\text { departments } \\
\text { or customer }\end{array}$ & $\begin{array}{l}\text { Auxiliary } \\
\text { departments or } \\
\text { customer }\end{array}$ & $\begin{array}{l}\text { Material scope of } \\
\text { changes }\end{array}$ \\
\hline & & $\begin{array}{l}\text { product is made. Notice that this change can } \\
\text { influence on parts dimensional stability and } \\
\text { need to go together with IMDS system } \\
\text { change according to IATF standards. }\end{array}$ & $\begin{array}{l}\text { Quality } \\
\text { Customer }\end{array}$ & & \\
\hline 5 & Part history $\log$ & $\begin{array}{l}\text { Updating the history of all existing changes } \\
\text { (logs) saved and sending it to customer. All } \\
\text { changes need to be tracked and marked with } \\
\text { part number change, production and first } \\
\text { shipments to customer dates. }\end{array}$ & $\begin{array}{l}\text { Engineering } \\
\text { Quality }\end{array}$ & Not required & $\begin{array}{l}\text { Change of } \\
\text { documentation }\end{array}$ \\
\hline 6 & Part revision change & $\begin{array}{l}\text { Each engineering change should rise up } \\
\text { affected parts revision, Changing the part } \\
\text { number for production is given in the form } \\
\text { of an engraver, stamp, label or with any } \\
\text { other marking. }\end{array}$ & $\begin{array}{l}\text { Engineering } \\
\text { Production } \\
\text { Quality }\end{array}$ & $\begin{array}{l}\text { The head of } \\
\text { production } \\
\text { unit } \\
\text { Logistics } \\
\text { Maintenance }\end{array}$ & Product \\
\hline 7 & BOM update & $\begin{array}{l}\text { Update of the list of materials and } \\
\text { components (BOM) used for the production } \\
\text { of a given product. BOM correctness is very } \\
\text { important for inventory status in ERP } \\
\text { system. Every missed information may have } \\
\text { direct influence on inventorisation results. }\end{array}$ & Engineering & $\begin{array}{l}\text { Production } \\
\text { Logistics }\end{array}$ & $\begin{array}{l}\text { Change of } \\
\text { documentation }\end{array}$ \\
\hline 8 & $\begin{array}{l}\text { Updating the } \\
\text { information on the label } \\
\text { / sticker / laserprint }\end{array}$ & $\begin{array}{l}\text { If parts are tracked and mark with part } \\
\text { revision or production batch - this marking } \\
\text { should be updated. }\end{array}$ & $\begin{array}{l}\text { Engineering } \\
\text { Quality }\end{array}$ & $\begin{array}{l}\text { Production } \\
\text { Customer } \\
\text { Logistics } \\
\text { Warehouse } \\
\end{array}$ & Indirect process \\
\hline 9 & $\begin{array}{l}\text { Updating 2D } \\
\text { documentation }\end{array}$ & $\begin{array}{l}\text { All changes including dimensions, } \\
\text { tolerances, material, revision, marking etc } \\
\text { changes should be included in } 2 \mathrm{~d} \text { drawing as } \\
\text { this document is a baseline for process } \\
\text { preparation. Also, drawings are usually a } \\
\text { baseline specification for external claims. }\end{array}$ & Engineering & Quality & $\begin{array}{l}\text { Change of } \\
\text { documentation }\end{array}$ \\
\hline 10 & $\begin{array}{l}\text { Transfer of 2D } \\
\text { documentation to all } \\
\text { required departments } \\
\text { for expressing opinions } \\
\end{array}$ & $\begin{array}{l}\text { Sharing documentation with all affected } \\
\text { departments within the company. }\end{array}$ & $\begin{array}{l}\text { Engineering } \\
\text { Production } \\
\text { Quality } \\
\end{array}$ & $\begin{array}{l}\text { The head of } \\
\text { production } \\
\text { unit }\end{array}$ & $\begin{array}{l}\text { Change of } \\
\text { documentation }\end{array}$ \\
\hline 11 & $\begin{array}{l}\text { Change of the } \\
\text { machine/tools used for } \\
\text { producing the product. }\end{array}$ & $\begin{array}{l}\text { Some engineering changes are forcing tools / } \\
\text { machines changes within machine park. }\end{array}$ & $\begin{array}{l}\text { Engineering } \\
\text { Production } \\
\text { The head of } \\
\text { production } \\
\text { unit }\end{array}$ & $\begin{array}{l}\text { Maintenance } \\
\text { Quality } \\
\text { Customer }\end{array}$ & Direct process \\
\hline 12 & $\begin{array}{l}\text { Modification of the } \\
\text { machine park/tools for } \\
\text { the purpose of } \\
\text { introducing an } \\
\text { engineering change. }\end{array}$ & $\begin{array}{l}\text { Some engineering changes are forcing tools / } \\
\text { machines modifications that have to be done } \\
\text { before final production. }\end{array}$ & $\begin{array}{l}\text { Engineering } \\
\text { Maintenance }\end{array}$ & Production & Direct process \\
\hline 13 & $\begin{array}{l}\text { Changing the layout of } \\
\text { machines on the } \\
\text { production floor. }\end{array}$ & $\begin{array}{l}\text { Engineering Change might force to change } \\
\text { production line layout. }\end{array}$ & $\begin{array}{l}\text { The head of } \\
\text { production } \\
\text { unit } \\
\text { Engineering } \\
\text { Production }\end{array}$ & Not required & Direct process \\
\hline 14 & $\begin{array}{c}\text { Checking the } \\
\text { production process in } \\
\text { terms of performance } \\
\text { and quality (Run \& } \\
\text { Rate). } \\
\end{array}$ & $\begin{array}{l}\text { Final check of engineering change } \\
\text { performance in production process - } \\
\text { efficiency, quality and downtimes. }\end{array}$ & $\begin{array}{l}\text { Engineering } \\
\text { Production } \\
\text { Quality }\end{array}$ & $\begin{array}{l}\text { The head of } \\
\text { production } \\
\text { unit }\end{array}$ & Direct process \\
\hline 15 & $\begin{array}{l}\text { Developing process } \\
\text { sheet. }\end{array}$ & $\begin{array}{l}\text { Machines, tools and other equipment setup } \\
\text { and parameters sheet created by engineers } \\
\text { during trials. This is base information for } \\
\text { shop floor workers to keep process stable. }\end{array}$ & Engineering & Production & $\begin{array}{l}\text { Direct process } \\
\text { and change of } \\
\text { documentation }\end{array}$ \\
\hline 16 & Packing & $\begin{array}{l}\text { Changing the way of packing and } \\
\text { transporting products. Often it has to be } \\
\text { approve based on packaging and } \\
\text { transportation trials. }\end{array}$ & $\begin{array}{l}\text { Engineering } \\
\text { Logistics }\end{array}$ & $\begin{array}{l}\text { Production } \\
\text { Warehouse }\end{array}$ & Indirect process \\
\hline 17 & $\begin{array}{l}\text { Significant change in } \\
\text { labour intensity }\end{array}$ & $\begin{array}{l}\text { Analysis of demand for human resources, } \\
\text { Methods Time Measurement - MTM }\end{array}$ & $\begin{array}{l}\text { Engineering } \\
\text { Production } \\
\text { The head of } \\
\text { production } \\
\text { unit } \\
\end{array}$ & Not required & Direct process \\
\hline 18 & $\begin{array}{l}\text { Update of production } \\
\text { parameters (cycle, Takt } \\
\text { time, lead time) }\end{array}$ & $\begin{array}{l}\text { Update needs to be done both in documents } \\
\text { and machines. }\end{array}$ & $\begin{array}{l}\text { Engineering } \\
\text { Production }\end{array}$ & Not required & Direct process \\
\hline 19 & Development of the & Manual for production operators and & Engineering & Not required & Change of \\
\hline
\end{tabular}


MODERN SOLUTIONS IN PRODUCTION AND WAREHOUSING

\begin{tabular}{|c|c|c|c|c|c|}
\hline $\begin{array}{c}\text { Task } \\
\text { number }\end{array}$ & Name of task & Description & $\begin{array}{c}\text { Main } \\
\text { departments } \\
\text { or customer }\end{array}$ & $\begin{array}{c}\text { Auxiliary } \\
\text { departments or } \\
\text { customer }\end{array}$ & $\begin{array}{l}\text { Material scope of } \\
\text { changes }\end{array}$ \\
\hline & work instructions & $\begin{array}{c}\text { technicians describing operations, correct } \\
\text { sequence and safety rules of performing } \\
\text { production process }\end{array}$ & & & documentation \\
\hline 20 & $\begin{array}{c}\text { Determining } \\
\text { technological } \\
\text { capabilities (machine } \\
\text { feasibility) }\end{array}$ & $\begin{array}{c}\text { Engineers need to make sure that present } \\
\text { machine park is ready and able to produce } \\
\text { parts after EC. }\end{array}$ & Engineering & $\begin{array}{l}\text { The head of } \\
\text { production } \\
\text { unit } \\
\text { Production }\end{array}$ & Direct process \\
\hline 21 & $\begin{array}{c}\text { Determining supplier } \\
\text { capabilities (supplier } \\
\text { feasibility) }\end{array}$ & $\begin{array}{c}\text { If suppliers are involved in EC they need to } \\
\text { be verified in terms of feasibility and } \\
\text { capacity. }\end{array}$ & $\begin{array}{l}\text { Engineering } \\
\text { Logistics }\end{array}$ & Quality & Indirect process \\
\hline 22 & $\begin{array}{l}\text { Performing tests after } \\
\text { the pilot batch }\end{array}$ & $\begin{array}{l}\text { Depending on Customer requirements } \\
\text { specify tests need to be done to approve } \\
\text { implementation process. }\end{array}$ & $\begin{array}{l}\text { Engineering } \\
\text { Quality }\end{array}$ & Not required & Direct process \\
\hline 23 & $\begin{array}{l}\text { Changing the shipping } \\
\text { label }\end{array}$ & $\begin{array}{l}\text { Shipping label changes according to } \\
\text { engineering change. }\end{array}$ & $\begin{array}{l}\text { Engineering } \\
\text { Logistics }\end{array}$ & Not required & $\begin{array}{l}\text { Indirect process } \\
\text { and change of } \\
\text { documentation }\end{array}$ \\
\hline 24 & $\begin{array}{l}\text { Prototype making } \\
\text { change }\end{array}$ & $\begin{array}{l}\text { If Engineering change requires to create } \\
\text { prototype parts before release it need to be } \\
\text { marked accordingly. It is a change of the test } \\
\text { / trial part number not released into the } \\
\text { production process, usually in the form of a } \\
\text { label on part or packaging container. }\end{array}$ & $\begin{array}{l}\text { Engineering } \\
\text { Quality }\end{array}$ & Logistics & Indirect process \\
\hline 25 & $\begin{array}{l}\text { PFD update (process } \\
\text { flow diagram) }\end{array}$ & $\begin{array}{c}\text { This document is part of APQP and needs to } \\
\text { be prepared as a part of PPAP and part of } \\
\text { IATF requirement. }\end{array}$ & Engineering & Quality & $\begin{array}{c}\text { Change of } \\
\text { documentation }\end{array}$ \\
\hline 26 & $\begin{array}{l}\text { FMEA update (analysis } \\
\text { of the types and effects } \\
\text { of possible errors, } \\
\text { Failure Mode and } \\
\text { Effects Analysis - } \\
\text { FMEA) }\end{array}$ & $\begin{array}{c}\text { This document is part of APQP and needs to } \\
\text { be prepared as a part of PPAP and part of } \\
\text { IATF requirement. IATF is strongly focused } \\
\text { on risk analyses - FMEA as well. This } \\
\text { should be prepared in interdisciplinary } \\
\text { teams. }\end{array}$ & $\begin{array}{l}\text { Engineering } \\
\text { Quality }\end{array}$ & Production & $\begin{array}{c}\text { Change of } \\
\text { documentation }\end{array}$ \\
\hline 27 & $\begin{array}{l}\text { Changing patterns for } \\
\text { error checking - error } \\
\text { proofing samples (poka- } \\
\text { yoke samples) }\end{array}$ & $\begin{array}{l}\text { Error-proofing is required by IATF } \\
\text { certification for all special characteristics } \\
\text { and process control. Before every production } \\
\text { run all control points should be checked and } \\
\text { confirmed as correctly working. }\end{array}$ & $\begin{array}{l}\text { Engineering } \\
\text { Production } \\
\text { Quality }\end{array}$ & Not required & Indirect process \\
\hline 28 & $\begin{array}{l}\text { Checking the machine } \\
\text { availability in terms of } \\
\text { technology (machine } \\
\text { capacity) and } \\
\text { determining the } \\
\text { required buffer of parts }\end{array}$ & $\begin{array}{c}\text { EC might enlarge production takt time/lead } \\
\text { times what will have influence of accessible } \\
\text { time. }\end{array}$ & $\begin{array}{l}\text { Engineering } \\
\text { Production }\end{array}$ & $\begin{array}{l}\text { The head of } \\
\text { production } \\
\text { unit }\end{array}$ & Direct process \\
\hline 29 & $\begin{array}{l}\text { Registration of a new } \\
\text { material supplier } \\
\text { according to norm } \\
\text { ISO9001 }\end{array}$ & $\begin{array}{l}\text { Registration need to be performed within } \\
\text { company database. }\end{array}$ & $\begin{array}{l}\text { Engineering } \\
\text { Quality }\end{array}$ & $\begin{array}{l}\text { Logistics } \\
\text { (purchasing) }\end{array}$ & $\begin{array}{c}\text { Change of } \\
\text { documentation }\end{array}$ \\
\hline 30 & $\begin{array}{c}\text { Validation tests / } \\
\text { material certification } \\
\text { (Design Validation Plan } \\
\text { and Report - DVPR) } \\
\end{array}$ & $\begin{array}{l}\text { This is test showing if product design is } \\
\text { efficient and have no failures. Specific tests } \\
\text { are usually required by OEMs depending on } \\
\text { final part material, design and functionality. }\end{array}$ & $\begin{array}{l}\text { Engineering } \\
\text { Quality }\end{array}$ & Not required & Indirect process \\
\hline 31 & $\begin{array}{l}\text { The way of using the } \\
\text { parts in stock buffer } \\
\text { before the change in } \\
\text { production (running } \\
\text { change, stock scrap) }\end{array}$ & $\begin{array}{l}\text { Assessment whether after the engineering } \\
\text { change the inventory should be disposed of } \\
\text { before the change, or it can be used }\end{array}$ & $\begin{array}{l}\text { Engineering } \\
\text { Logistics }\end{array}$ & Quality & Indirect process \\
\hline 32 & $\begin{array}{l}\text { Change / modification } \\
\text { of controls and } \\
\text { measuring devices. }\end{array}$ & $\begin{array}{c}\text { Production is controlled by specific } \\
\text { measures and devices that may need to be } \\
\text { modified. }\end{array}$ & $\begin{array}{l}\text { Engineering } \\
\text { Quality }\end{array}$ & Not required & Indirect process \\
\hline
\end{tabular}

Źródło: opracowanie własne.

Source: own work.

Production department is responsible for these tasks (table 2.).

Table 2. List of tasks from production department

\begin{tabular}{|c|c|c|c|c|c|}
\hline $\begin{array}{c}\text { Task } \\
\text { number }\end{array}$ & Name of task & Description & $\begin{array}{c}\text { Main } \\
\text { departments }\end{array}$ & $\begin{array}{c}\text { Auxiliary } \\
\text { departments or } \\
\text { customer }\end{array}$ & $\begin{array}{c}\text { Material scope } \\
\text { of changes }\end{array}$ \\
\hline 1 & Updating the plan of & This is a consequence of changing/adding & Maintenance & Engineering & Indirect process \\
\hline
\end{tabular}

Brzeziński Ł. et al. (Eds.), Modern solutions in production and warehousing, Spatium, Radom 2019.

https://doi.org/10.17270/B.M.978-83-66017-87-0.4 
MODERN SOLUTIONS IN PRODUCTION AND WAREHOUSING

\begin{tabular}{|c|c|c|c|c|c|}
\hline $\begin{array}{c}\text { Task } \\
\text { number }\end{array}$ & Name of task & Description & $\begin{array}{c}\text { Main } \\
\text { departments }\end{array}$ & $\begin{array}{c}\text { Auxiliary } \\
\text { departments or } \\
\text { customer }\end{array}$ & $\begin{array}{l}\text { Material scope } \\
\text { of changes }\end{array}$ \\
\hline & $\begin{array}{l}\text { machine and tooling } \\
\text { inspections (Preventive } \\
\text { Maintenance Schedule }\end{array}$ & tools/ machines to factory production park. & Production & & \\
\hline 2 & $\begin{array}{l}\text { Preparation of work } \\
\text { instructions for spare } \\
\text { parts. }\end{array}$ & $\begin{array}{l}\text { Every part number of final goods required to } \\
\text { have their spare part, which is sometimes } \\
\text { different by BOM or/and production process. } \\
\text { This need to be notify in special work } \\
\text { instruction. }\end{array}$ & $\begin{array}{l}\text { Maintenance } \\
\text { Production }\end{array}$ & Engineering & $\begin{array}{c}\text { Change of } \\
\text { documentation }\end{array}$ \\
\hline 3 & $\begin{array}{l}\text { Preparation and } \\
\text { training of machines } \\
\text { operators }\end{array}$ & $\begin{array}{l}\text { Training of machines operators to work } \\
\text { according to new rules and instructions - } \\
\text { including new operations, work instructions } \\
\text { and new standards review. }\end{array}$ & $\begin{array}{l}\text { Production } \\
\text { Engineering } \\
\text { The head of } \\
\text { production } \\
\text { unit }\end{array}$ & Not required & $\begin{array}{l}\text { Organizational } \\
\text { change }\end{array}$ \\
\hline 4 & $\begin{array}{l}\text { Update of ANDON } \\
\text { system settings } \\
\text { (information exchange } \\
\text { in production } \\
\text { processes) }\end{array}$ & $\begin{array}{l}\text { ANDON is a fast response system for } \\
\text { production control. System is usually } \\
\text { calculating line efficiency, scrap levels and } \\
\text { other production parameters so every change } \\
\text { need to be updated to collect correct } \\
\text { information. }\end{array}$ & $\begin{array}{l}\text { Production } \\
\text { Engineering }\end{array}$ & $\begin{array}{l}\text { The head of } \\
\text { production unit }\end{array}$ & Direct process \\
\hline 5 & $\begin{array}{l}\text { Determining the } \\
\text { amount of parts in } \\
\text { stock buffer before the } \\
\text { change is implemented }\end{array}$ & $\begin{array}{l}\text { Often implementation the change request } \\
\text { process is forcing to shutdown production } \\
\text { lines and machines. For that reason, final } \\
\text { parts need to be produced on buffer. }\end{array}$ & $\begin{array}{l}\text { Production } \\
\text { Logistics } \\
\text { The head of } \\
\text { production } \\
\text { unit } \\
\text { Engineering } \\
\end{array}$ & Not required & Indirect process \\
\hline
\end{tabular}

Źródło: opracowanie własne.

Source: own work.

Quality department is responsible for these tasks (table 3.).

Table 3. List of tasks from quality department

\begin{tabular}{|c|c|c|c|c|c|}
\hline $\begin{array}{c}\text { Task } \\
\text { number }\end{array}$ & Name of task & Description & $\begin{array}{c}\text { Main } \\
\text { departments }\end{array}$ & $\begin{array}{l}\text { Auxiliary } \\
\text { departments or } \\
\text { customer }\end{array}$ & Material scope of changes \\
\hline 1 & $\begin{array}{l}\text { Update of the control } \\
\text { plan (Control Plan } \\
\text { document) }\end{array}$ & $\begin{array}{l}\text { This document is part of APQP } \\
\text { and needs to be prepared as a part } \\
\text { of PPAP and part of IATF } \\
\text { requirement. Control plan is based } \\
\text { document for many audits in } \\
\text { automotive industry. }\end{array}$ & $\begin{array}{c}\text { Quality } \\
\text { Engineering }\end{array}$ & Production & Change of documentation \\
\hline 2 & $\begin{array}{l}\text { Checking the } \\
\text { correctness of the } \\
\text { selected system and } \\
\text { measurement system } \\
\text { analysis (MSA) }\end{array}$ & $\begin{array}{l}\text { Each measurement equipment } \\
\text { needs to be check if system } \\
\text { equipment }+ \text { operator can be } \\
\text { metrologically efficient. }\end{array}$ & $\begin{array}{c}\text { Quality } \\
\text { Engineering }\end{array}$ & Not required & Indirect process \\
\hline 3 & $\begin{array}{l}\text { Development of } \\
\text { incoming inspection } \\
\text { instructions }\end{array}$ & $\begin{array}{l}\text { Change of the inspection plan on } \\
\text { the supply control (frequency, type } \\
\text { of control) }\end{array}$ & $\begin{array}{c}\text { Quality } \\
\text { Engineering }\end{array}$ & Not required & Indirect process \\
\hline 4 & $\begin{array}{l}\text { Development of quality } \\
\text { inspection instructions }\end{array}$ & $\begin{array}{c}\text { Change of instructions according } \\
\text { to which the measurement of the } \\
\text { product is to be made }\end{array}$ & $\begin{array}{c}\text { Quality } \\
\text { Engineering }\end{array}$ & Not required & Change of documentation \\
\hline 5 & $\begin{array}{l}\text { Development of visual } \\
\text { inspection instructions }\end{array}$ & $\begin{array}{c}\text { Change of instructions on } \\
\text { checking the visual aspects of the } \\
\text { product }\end{array}$ & $\begin{array}{c}\text { Quality } \\
\text { Engineering }\end{array}$ & Not required & Change of documentation \\
\hline 6 & $\begin{array}{l}\text { Development of quality } \\
\text { control charts }\end{array}$ & $\begin{array}{l}\text { Control of special characteristics } \\
\text { of the product (e.g. weight, } \\
\text { functional dimension) }\end{array}$ & $\begin{array}{c}\text { Quality } \\
\text { Engineering }\end{array}$ & Production & $\begin{array}{l}\text { Indirect process and change } \\
\text { of documentation }\end{array}$ \\
\hline 7 & $\begin{array}{l}\text { Report of visual } \\
\text { inspection of parts } \\
\text { produced after the } \\
\text { change (Appearance } \\
\text { Approval Report - } \\
\text { AAR) }\end{array}$ & $\begin{array}{l}\text { Document that customer approves } \\
\text { visual parts appearance. }\end{array}$ & Quality & Engineering & Indirect process \\
\hline 8 & $\begin{array}{c}\text { Part approval by the } \\
\text { customer (Production } \\
\text { Part Approval Process - } \\
\text { PPAP) } \\
\end{array}$ & $\begin{array}{l}\text { Final package of documents, often } \\
\text { including final goods physically } \\
\text { that is presented to customer and } \\
\text { needs to be approved. }\end{array}$ & $\begin{array}{l}\text { Quality } \\
\text { Engineering } \\
\text { Customer }\end{array}$ & Not required & Change of documentation \\
\hline
\end{tabular}


MODERN SOLUTIONS IN PRODUCTION AND WAREHOUSING

\begin{tabular}{|c|c|c|c|c|c|}
\hline 9 & $\begin{array}{c}\text { Rating of Customer } \\
\text { Special Requirements } \\
\text { (CSR) }\end{array}$ & $\begin{array}{c}\text { Engineering change needs to be } \\
\text { verified if it doesn't violate CSR. }\end{array}$ & $\begin{array}{c}\text { Quality } \\
\text { Engineering }\end{array}$ & Not required & Change of documentation \\
\hline 10 & $\begin{array}{c}\text { Updating the IMDS } \\
\text { (International Material } \\
\text { Data System) database }\end{array}$ & $\begin{array}{c}\text { Global database for materials } \\
\text { specifications with assignation to } \\
\text { companies. }\end{array}$ & $\begin{array}{c}\text { Quality } \\
\text { Engineering }\end{array}$ & Not required & Change of documentation \\
\hline
\end{tabular}

Źródło: opracowanie własne.

Source: own work.

Logistics department is responsible for these tasks (table 4.).

Table 4. List of tasks from logistics department

\begin{tabular}{|c|c|c|c|c|c|}
\hline $\begin{array}{c}\text { Task } \\
\text { number }\end{array}$ & Name of task & Description & $\begin{array}{c}\text { Main } \\
\text { departments }\end{array}$ & $\begin{array}{c}\text { Auxiliary } \\
\text { departments or } \\
\text { customer }\end{array}$ & $\begin{array}{c}\text { Material } \\
\text { scope of } \\
\text { changes }\end{array}$ \\
\hline 1 & $\begin{array}{c}\text { Receival of materials and } \\
\text { components }\end{array}$ & $\begin{array}{c}\text { Delivery of goods required for test batches, } \\
\text { proto runs and Run\&Rate production. }\end{array}$ & $\begin{array}{c}\text { Logistics } \\
\text { Warehouse }\end{array}$ & Not required & $\begin{array}{c}\text { Indirect } \\
\text { process }\end{array}$ \\
\hline 2 & $\begin{array}{c}\text { Receival of components } \\
\text { and materials for the trial } \\
\text { series. }\end{array}$ & $\begin{array}{c}\text { It is about making sure that new components } \\
\text { are in the factory ready to use for first } \\
\text { production run after change. }\end{array}$ & $\begin{array}{c}\text { Logistics } \\
\text { Engineering }\end{array}$ & Not required & $\begin{array}{c}\text { Indirect } \\
\text { process }\end{array}$ \\
\hline 3 & $\begin{array}{c}\text { Change location of } \\
\text { inventory }\end{array}$ & $\begin{array}{c}\text { Change location of inventory (components, } \\
\text { materials and finished products) in the } \\
\text { warehouse (for parts before and after } \\
\text { engineering change) }\end{array}$ & Logistics & Not required & $\begin{array}{c}\text { Indirect } \\
\text { process }\end{array}$ \\
\hline 5 & $\begin{array}{c}\text { Change of destination for } \\
\text { shipments of final } \\
\text { products }\end{array}$ & $\begin{array}{c}\text { EC may open new target destination for final } \\
\text { goods - this has to be verified and plant needs } \\
\text { to be prepared for incoming/shipments } \\
\text { schedules change. }\end{array}$ & Logistics & Not required & $\begin{array}{c}\text { Indirect } \\
\text { process }\end{array}$ \\
\hline 6 & $\begin{array}{c}\text { EDI upgrade for customer } \\
\text { orders (Electronic Data } \\
\text { Interchange) }\end{array}$ & $\begin{array}{c}\text { EC force to rise revision of final goods, and } \\
\text { this need to be clearly stated in orders ass } \\
\text { well. Customer should inform from what date } \\
\text { new revision is required. }\end{array}$ & Logistics & Customer & $\begin{array}{c}\text { Indirect } \\
\text { process }\end{array}$ \\
\hline $\begin{array}{c}\text { Implementation of } \\
\text { assumptions regarding the } \\
\text { preparation of a safety } \\
\text { stock }\end{array}$ & $\begin{array}{c}\text { Meaning realising scheduled production plan } \\
\text { and additional needs }\end{array}$ & Logistics & $\begin{array}{c}\text { The head of } \\
\text { production unit } \\
\text { Engineering }\end{array}$ & $\begin{array}{c}\text { Indirect } \\
\text { process }\end{array}$ \\
\hline
\end{tabular}

Źródło: opracowanie własne.

Source: own work.

\section{CONCLUSICE REMARKS}

Created list of necessary tasks in implementing engineering changes in automotive companies is a useful tool for managers. This list can take a role of a checklist that can come in handy for engineering changes management.

In practice of specific company from the automotive industry, both the list of tasks and the allocation to individual departments may be partly differ. The main reasons for the differences may be:

- $\quad$ specificity of offered products (including their technical complexity),

- scope of engineering changes,

- various organizational chart and department names.

The aim of the authors of the chapter was to develop a list of largely universal, which can be adapted to the any conditions of the company from automotive industry. 


\section{ACKNOWLEDGMENTS}

This chapter was funded by the Poznan University of Technology, Faculty of Engineering Management [project number: 11/140/SBAD/4168].

\section{REFERENCES}

Bartnicki M., 1998, Zarządzanie zmianami w przedsiębiorstwie [Enterprise change management], Wydawnictwo Akademii Ekonomicznej w Katowicach, Katowice, s. 9.

BMW Group Customer Specific Requirements for IATF 16949:2016 - September 2017.

Buergin, J., Belkadi, F., Hupays, C., Gupta, R.K., Bitte, F., Lanza, G. and Bernard, A., 2018. A modular-based approach for Just-In-Time Specification of customer orders in the aircraft manufacturing industry. CIRP Journal of Manufacturing Science and Technology, 21, pp.61-74, DOI: 10.1016/j.cirpj.2018.01.003.

Bukłaha E., 2012, Zarządzanie projektami, a zarządzanie zmianą [Project management and change management], Warszawa, Szkoła Główna Handlowa w Warszawie.

Clarke L., 1997, Zarządzanie zmianą, Wydawnictwo Gegethner\&Ska., Warszawa, s. 58.

Daimler AG Customer Specific Requirements for IATF 16949:2016 - September 2017.

ElMaraghy HA, (Ed.), 2009, Changeable and Reconfigurable Manufacturing Systems. Springer London, London, DOI:10.1007/978-1-84882-067-8.

Ford Motor Company Customer Specific Requirements for IATF 16949:2016 - effective May 2017.

General Motors Customer Specific Requirements for IATF 16949:2016 - Effective June 1, 2019.

International Automotive Task Force, IATF 16949:2016.

Koren Y, 2010, The global manufacturing revolution: Product-process-business integration and reconfigurable systems. Wiley, Hoboken, N.J.

Koren Y, Shpitalni M, 2010, Design of reconfigurable manufacturing systems. Journal of Manufacturing Systems 29(4):130-41, DOI: 10.1016/j.jmsy.2011.01.001.

Mikołajczyk Z., 2003, Zarzadzanie procesem zmian w organizacjach. Zarządzanie zmianą ujęcie teoretyczne [Managing the process of changes in organizations. Change management - theoretical approach], Projekt „Partnerski System Zarządzania Zmianą Gospodarczą na Obszarach Natura 2000” nr POKL.08.01.02-20-027/11, Wydawnictwo Dolnośląskiej Wyższej Szkoły Handlowej im. Wojciecha Korfantego w Katowicach, Katowice, s. 13. 
PSA Group Customer Specific Requirements for use with IATF 16949:2016Effective Feb 15, 2017.

Renault Group Customer Specific Requirements for IATF 16949 - July 2017.

Rossini, M., Ciarapica, F., Matt, D. and Spena, P.R., 2016. A preliminary study on the changes in the Italian automotive supply chain for the introduction of electric vehicles. Journal of Industrial Engineering and Management, 9(2), pp.450-486, DOI: 10.3926/jiem.1504.

Sivri, S.D. and Krallmann, H., 2015. Process-oriented knowledge management within the product change systems of the automotive industry. Procedia Engineering, 100, pp.10321039, DOI: 10.1016/j.proeng.2015.01.463.

Tido Eger, Claudia M Eckert, P John Clarkson, 2007, Engineering change analysis during ongoing product development, INTERNATIONAL CONFERENCE ON ENGINEERING DESIGN, ICED’07, p.3.

Urban-Galindo, J.J. and Ripailles, S., 2019. PLM at GROUPE PSA. In Product Lifecycle Management (Volume 4): The Case Studies (pp. 29-50). Springer, Cham, DOI: 10.1007/978-3-030-16134-7.

Volkswagen Group Customer Specific Requirements for use with IATF 16949:2016 January 2018.

Wirkus M., Roszkowski H., Dostatni E., Gierulski W., 2014, Zarządzanie Projektem [Project management], Warszawa, PWE.

Wysocki Robert K., 2005, Efektywne Zarządzanie Projektami [Effective project management], Gliwice, Helion. 